Ann. Zootech., I979, 28 (3), 235-238.

I.N.R.A.

BIBLIOTHEQUE UO 35905

Domaine de Crovellé

63039

Clermont-FD Cenex 2

\title{
A note on performance of Holstein Friesian veal calves raised to weaning individually or in groups
}

\author{
G. LALANDE, K. BEAUCHEMIN and M. H. FAHMY \\ Canada Agriculture, Research Station, \\ P.O. Box 9o, Lennoxville, Quebec, Canada, JIM ${ }_{1} Z_{3}$
}

\begin{abstract}
Summary
Fourty-eight male Holstein-Friesian veal calves were raised from an average of 50 to a weaning weight of $93 \mathrm{~kg}$, either tied individually, loose in groups of 4 , or in groups of 8 . Three individually-fed and 9 group-fed calves died before weaning some of them due to initoxication by insecticides used in the barn. In the three treatments, each calf was provided with one nipple and $0.75 \mathrm{~m}^{2}$ of space. All the individually fed calves were fed from the same cotitainer. Feeding was ad libitum on milk substitute offered at to p. Ioo of the animals' body weight and the amount was adjusted each week to correspond to changes in calves weight. The percent of milk consumed of milk offered was similar for the three treatments (ranged from 86.0 to 89.0 p. 100). However, feed conversion ratio was higher for calves raised individually (2.26 TDN / weight gained), than for those reared in groups of 4 or 8 which had similar feed conversion ratios (I.6I and I.5I). Average daily gain was higher for calves raised in groups as compared to those raised individually, the difference of $0.23 \mathrm{~kg}$ with those raised in groups of 4 , being significant $(\mathrm{P}<0.05)$. Calves reared individually took almost three weeks longer to reach weaning weight than those reared in groups.
\end{abstract}

\section{Introduction}

In comparison to the extensive research that has been done in the past on the nutritional requirements of veal calves, the extent to which housing affects the growth and development of the calf has been given little consideration. Most of the work to improve housing and management dealt mainly with controlling environment such as temperature, humidity, and ventilation (BOURNE, I969; Thompson, I966; Mitcheli and BroadBent, I973) or housing design (KILGOUR et al., I975).

WARnick, ANAVE and Mickelsen (I977) reported that calves raised in isolation had slower gains than either individually- or group-reared calves. Apart from that report, little documentation exists on the performance of calves raised individually as compared to those reared in groups, and the appropriate size of these groups, which makes the subject of the present report. 


\section{Material and methods}

Fourty-eight male Holstein-Friesian veal calves (ranging from $\mathrm{I}$ to 6 days of age, and weighing from 37 to $63 \mathrm{~kg}$, average, $47 \mathrm{~kg}$ ) were purchased from producers in the neighbourhood of the Lennoxville Station. They were weighed at purchase, and then every subsequent week until weaning at about $93 \mathrm{~kg}$ live weight.

At the research station, the calves were assigned to one of three treatments. These were: A, four pens of 4 calves each; B, three pens of 8 calves each; and $\mathrm{C}$, eight calves reared individually. The individually reared calves were tied whereas those in groups were left untied. Data were collected following an adaptation period of approximately two weeks.

One nipple feeder and $0.75 \mathrm{~m}^{2}$ of space (plywood cages on concrete floor) were provided for each animal so that the number of nipples and space given to each group corresponded to the number of calves in the group. The number of nipples and space were reduced when animals raised in groups died, to allow always for $0.75 \mathrm{~m}^{2}$ and one nipple per animal.

The calves were fed a milk substitute at room temperature containing 23 p. Ioo protein, 20 p. Ioo fat, 72 p. Ioo TDN, diluted in water giving r 3 p. Ioo dry matter. The milk substitute was fed at ro p. Ioo of the animal's body weight, and was adjusted each week after weighing the animals. The milk was placed in a large container and conducted to the nipples through nalgon tubes. The animals were able to consume to their requirements, and the refused milk was weighed daily to determine actual milk consumption. The individually fed calves were all fed from the same container, therefore measuring feed conversion for each individual calf was not possible.

Feed conversion was expressed as a ratio of TDN to weight gain, and was calculated by dividing the total milk consumed by the total weight gained per group. The milk consumed was adjusted to account for the milk used by calves that died during the week. Weight gain was calculated per group by subtracting the initial from the final weight of all animals in each group. Average daily gain was calculated for each calf individually. The data on growth rate were analyzed using Harvey's least-squares analysis of variance (HARver, I960). Average daily gain was adjusted for initial and final weights by including these factors as continuous variables.

\section{Results}

Twelve of the 48 calves initiated on the experiment died before weaning, 3 (37 p. IOO) in the individually-fed and $9(22 \mathrm{p}$. IOO) in the group-fed treatments (table I). The calves that showed signs of scour prior to death also were found to have stomach ulcers when autopsies were performed. A certain proportion of these deaths were attributed to insecticides used in the barn. Examination of the carcasses revealed traces of the insecticides and discoloration of the kidney and liver. Sucking each other was a problem with calves in groups, two fatal cases revealed a blockage of the pylorus by a ball of hair.

The percent of milk replacer consumed of milk offered was similar for the 3 treatments. However, feed conversion ratio was higher for calves raised indi- 
TABLE I

Performance of calves raised individually or in groups

\begin{tabular}{|c|c|c|c|}
\hline & 8 individuals & 4 groups of 4 & 3 groups of 8 \\
\hline Initial number of calves & 8 & I 6 & 24 \\
\hline Number of calves weaned. . . . . . . & 5 & I 2 & I9 \\
\hline Mortality (p. roo) . . . . . . . & $37 \cdot 5$ & 25.0 & 20.8 \\
\hline Average initial body weight $(\mathrm{kg})\left({ }^{*}\right)$. & \pm 3.2 & $\pm 2 . I$ & 土 I.7 \\
\hline Average weaning weight $(\mathrm{kg})\left({ }^{*}\right)$ & $\pm \quad 1.0$ & 土 0.6 & $\pm \quad 0.5$ \\
\hline Average daily gain $(\mathrm{g}) . . . \ldots$ & $478(a)$ & $704(b)$ & $665(b) \pm 45$ \\
\hline No. of days to reach weaning weight & $92.8\left(^{a}\right) \pm 10.5$ & $65.7(b) \pm 6.7$ & $70.2(b)+5.3$ \\
\hline Percent milk consumed per offered. & 86.0 & 88.3 & 88.7 \\
\hline $\begin{array}{c}\text { Average daily dry matter consumed } \\
(\mathrm{kg}) . . \\
.\end{array}$ & I. 28 & I. 28 & I. 26 \\
\hline Feed conversion ratio ( $\mathrm{TDN} / \mathrm{wt}$ gain) & 2.26 & I.6I & I. $5 \mathrm{I}$ \\
\hline
\end{tabular}

(*) Of calves finishing the test.

$\left({ }^{a-b}\right)$ Means followed by different letters are significantly different $(\mathbf{P}<0.05)$.

vidually, than for those reared in groups which had similar feed conversions (table $x$ ). Average daily gain was higher for calves raised in groups as compared to those raised individually, the difference with those raised in groups of 4 , being significant $(\mathrm{P}<0.05)$. Accordingly, calves reared individually took more than 3 weeks longer to reach final weight than those raised in groups.

\section{Discussion}

The conventional system of individual rearing of veal has always been highly recommended as a precautionary measure for reducing and controlling disease to which calves are highly susceptible. Greater risks of disease and parasite transfer are associated with calves raised in groups (BouRne, Ig6g). Yet the extent to which calf housing affects calf growth and development has received little attention.

Growth rate of the veal calves in this experiment was significantly affected by the system of rearing. Calves reared conventionally in individual stalls although consuming relatively equal amounts of milk, gained less weight per day, and required more feed per weight gained as compared to those reared in groups. WARNICK et al. (I977) found that calves raised in groups consumed more feed as well as gained more weight as compared to calves reared individually or in isolation. The effect of group environment may be reducing the stress by permitting the calf to move freely, thus enabling calves to better assimilate nutrients, as evidence from the higher feed efficiency of the group-reared calves. Average daily gain was also significantly improved by group rearing, allowing calves to reach the weaning weight earlier. 
However, since the greatest danger to any one animal is the excreta and secretions (faeces, urine, saliva) of another animal (BouRNE, I967), group rearing is recommended only when in conjunction with carefull management.

Accepté pour publication en avril 1979.

\section{Résumé}

\section{Note sur les performances de veaux mâles de boucherie Holstein-Friesan élevés jusqu'au sevrage individuellement ou en groupe}

On a élevé 48 veaux mâles de boucherie Holstein-Friesian de $50 \mathrm{~kg}$ jusqu'au sevrage. Pour les besoins de l'expérience, on les a disposés de deux façons : soit attachés dans des stalles individuelles, soit laissés libres dans des cases de 4 ou de 8 . Dans les 2 cas, les veaux pouvaient s'alimenter à volonté à même un lactoduc. Pour tous les traitements, on a alloué à chaque veau une tétine et $0,75 \mathrm{~m}^{2}$ de plancher. Douze des 48 veaux utilisés dans l'expérience (3 "individuels" et 9 " groupes ") moururent avarit le sevrage. A l'autopsie, on a trouvé des ulcères d'estomac chez les veaux qui avaient été atteints de diarrhée avant la mort. Des examens de laboratoire ont démontré qu'une certaine proportion des mortalités était liée à une intoxication par les insecticides employés dans l'étable.

La quantité de lait consommée par rapport à celle offerte fut semblable pour les 3 traitements, variant de 86,0 à 89,0 p. Ioo. Cependant, l'indice de consommation des veaux élevés individuellement a été moins bon $(2,26 \mathrm{TDN} /$ gain de poids) que celui des animaux élevés en groupes de 4 ou de 8 .

Ces groupes ont eu un indice semblable, $I, 6 I$ et $I, 5 I$ respectivement. Les veaux élevés en groupes ont présenté un gain de poids journalier supérieur à celui des animaux élevés individuellement $(0,478 \mathrm{~kg})$. Ce gain s'est traduit par une différence significative $(\mathrm{P}<0,05)$ de $0,23 \mathrm{~kg}$ en faveur des groupes de 4 . Les animaux de l'élevage individuel ont mis 3 semaines de plus que ceux élevés en groupes à atteindre le poids de sevrage.

\section{References}

BOURNe F. J., I969. Housing the young calf. Vet. Rec., 85, 643-649.

HARVEY W. R., I960. Least-squares analysis of data with unequal subclass numbers. $U$. $S$. Dept. of Agr., ARS-20-8.

Kilgour R., Winfield C. G., Bremner K. J., Muliord M. M., DE Langen H., Hudson S. J., 1975. Behaviour of early weaned calves in indoor individual cubicles and group pens. $N . Z$. Vet. J., 23 (6), I19-」23.

Mitcheil, C. D., BrondBent P. J., I973. The effect of level and method of feeding milk substitute and housing environment on the performance of calves. Anim. Prod., 17, 245-256.

Thompson W. A., 1966. Calf rearing feature: calf housing and disease prevention. Agric. (London), 73, 272-277.

WarNick V. D., ANAvE C. W., Mickelsen C. H., 1977. Effects of group, individual, and isolated reating of calves on weight gain and behaviour. $J$. Dairy Sci., 60, 947-953. 